\title{
A Theoretical Framework Based on Organizational Cul- ture and Personnel Values (Case Study: Bandar Imam Petrochemicals)
}

\section{Un marco teórico basado en la cultura organizacional y los valores del personal (estudio de caso: Bandar Imam Petrochemicals)}

Sadegh Shattaly Nazhed Rovis

Islamic Azad University, Kerman, Iran.

ORCID: https://orcid.org/0000-0001-7039-0620

\section{Saeed Sayadi*}

Islamic Azad University, Kerman, Iran.

ORCID: https://orcid.org/0000-0003-2917-9043

\section{Masoud Pourkiani}

Islamic Azad University, Kerman, Iran.

ORCID: https://orcid.org/0000-0002-5370-3768

Farzaneh Beikzadeh Abbasi

Islamic Azad University, Kerman, Iran.

ORCID: https://orcid.org/0000-0002-2762-218X

Received 06-14-20 Revised 08-10-20 Accepted 09-01-20 On line 09-30-20

*Correspondence

Email: sayadi@iauk.ac.ir
Cite as:

Shattaly Nazhed Rovis, S., Sayadi, S., Pourkiani, M., \& Beikzadeh Abbasi, F. A. (2020). Theoretical Framework Based on Organizational Culture and Personnel Values (Case Study: Bandar Imam Petrochemicals). Propósitos y Representaciones, 8 (SPE3), $\quad$ e769. Doi: http://dx.doi.org/10.20511/pyr2020.v8nSPE3.769 


\section{Summary}

Today, it is necessary to learn to manage and administer organizations based on values, which is also influenced by the culture and atmosphere of the organization. No comprehensive research has been done on organizational culture and personnel values. Therefore, the purpose of this study is to provide a theoretical framework based on the components of organizational culture and personnel values in Bandar Imam Petrochemical. This research is applied in terms of purpose and descriptive-exploratory in terms of data collection method and with the help of a questionnaire. The statistical population of this study includes all employees of Bandar-e-Imam Petrochemical with a total of 3622 people. The said value is variable between 425 and 850 . Taking into account the probabilities related to the unusability of a number of completed questionnaires, a total of 620 questionnaires were randomly distributed in the desired area at different hours of the day, and finally 595 questionnaires were used as a basis for statistical analysis. (Organizational Culture Questionnaire and Personnel Values Questionnaire) was used. In this study, in order to determine the validity of the questionnaires through communication with elites (management professors) and the second-order confirmatory factor analysis model, all the proposed dimensions in this section (15 dimensions) were approved. Experts were located and the research model was approved. Cronbach's alpha coefficient was used for reliability of variables and questionnaires. To analyze the research data, factor analysis and confirmation of structural equation modeling and to fit the research model, SPSS and AMOS software were used. The results show that the research model has the necessary validity and there is a positive and significant relationship between organizational culture and personnel values in Bandar Imam Petrochemical. Finally, based on the importance and purpose, suggestions are presented.

Keywords: Organizational culture; Personnel values; Bandare imam petroleum.

\section{Resumen}

Hoy en día, es necesario aprender a gestionar y administrar organizaciones con base en valores, lo que también está influenciado por la cultura y el ambiente de la organización. No se ha realizado una investigación exhaustiva sobre la cultura organizacional y los valores del personal. Por lo tanto, el propósito de este estudio es brindar un marco teórico basado en los componentes de la cultura organizacional y los valores del personal en Bandar Imam Petrochemical. Esta investigación se aplica en términos de propósito y descriptivo-exploratorio en términos de método de recolección de datos y con la ayuda de un cuestionario. La población estadística de este estudio incluye a todos los empleados de Bandar-e-Imam Petrochemical con un total de 3622 personas. Dicho valor es variable entre 425 y 850 . Teniendo en cuenta las probabilidades relacionadas con la inutilización de varios cuestionarios cumplimentados, se distribuyeron aleatoriamente un total de 620 cuestionarios en la zona deseada a diferentes horas del día, y finalmente 595 cuestionarios fueron utilizado como base para el análisis estadístico. (Cuestionario de Cultura Organizacional y Cuestionario de Valores del Personal). En este estudio, con el fin de determinar la validez de los cuestionarios a través de la comunicación con las élites (profesores de gestión) y el modelo de análisis factorial confirmatorio de segundo orden, se aprobaron todas las dimensiones propuestas en este apartado (15 dimensiones). Se localizaron expertos y se aprobó el modelo de investigación. Se utilizó el coeficiente alfa de Cronbach para la confiabilidad de variables y cuestionarios. Para analizar los datos de la investigación, el análisis factorial y la confirmación del modelado de ecuaciones estructurales y para ajustar el modelo de investigación, se utilizó el software SPSS y AMOS. Los resultados muestran que el modelo de investigación tiene la validez necesaria y existe una relación positiva y significativa entre la cultura organizacional y los valores del personal en Bandar Imam Petrochemical. Finalmente, en base a la importancia y propósito, se presentan sugerencias.

Palabras clave: Cultura organizacional; Valores del personal; Bandare imam petroleum. 


\section{Introduction}

The word "Value" is one of the words that has the richest, the most complex and the most difficult meanings. Value is one of those words that is very rich in terms of meaning and therefore is very complex and can hardly be defined. Values often refer to the ideas that human beings have about good and bad, desirable and undesirable things. In Laland's philosophical culture, four concepts have been presented for value; first, value as something that an individual or group is interested in; second, something that is more or less considered and respected by some people; third, when an individual or group is satisfied in achieving their goal, and fourth, from an economic point of view, that the value of product and action is proposed (Mohseni, 2013). From the point of view of thinkers who have studied the category of culture and values, values are considerable at the individual, group, national and transnational levels. From the sociologists' point of view, individual values exist only if there are people who can evaluate objects and people. In this regard, social role is the most important mechanism by which individual values can be justified and symbolized.

In order for individual values to govern in the organization, first they should be known and also learn how to create these values in the essence of people and employees so that employees are committed to these values and apply them. It is obvious that in this regard, how to manage and administer organizations based on values should be learned, that this important issue is both influenced by the culture and the atmosphere of the organization; here the importance and the role of organizational culture in the implementation and management of organizations on the basis of values becomes necessary (Rajaipour \& Lafti, 2010).

\section{Literature Review}

\section{Organizational Culture}

Organizational culture is the existence of a system of common meanings and concepts among the members of the organization (Robbins, 2007). In the framework of the metaphor of organizational theories, Hatch considers culture as a metaphor for the organization and believes that the metaphor of culture emphasizes customs, traditions, and narrations and myths, human artifacts and organizational symbols (Hatch, 2009).

Organizational culture is a set of assumptions, beliefs, values, attitudes, thoughts, norms, feelings, actions and behaviors shared between the employees of an organization. Employees of the organization accept these ideas, values, norms, and behaviors, teach them to new employees, and act based on them (Mosadeghrad, 2006).

Šahic \& Stupar believes that culture is a property of the group. Whenever a common experience gathers in a group, a culture sprouts in it (Šahić \& Stupar, 2014). Some cultural dimensions can easily be recognized, but if we compare culture to a sea, knowing other cultural dimensions requires us to dive into the depths of this sea (Tolmats, 2003). In general, organizational culture has two dimensions; first, the guidance beliefs that are related to the beliefs of top managers of the organization and determine the direction of the organization movement and the daily beliefs of employees, and second, general and everyday beliefs that are related to all employees and are rooted in public culture of the community (Ahmadi, 2005) and (Mahmoudi, 2005).

According to Siegfried, culture is the soul of a community and distinguishes any community from other communities. In his book "Spirit of Nations", by studying the most significant cultural aspects of each one of the communities he has introduced German discipline, French intelligence and initiative, English stubbornness, American maturity and Iranian compatibility as the distinguishing features of these nations. Of course, compatibility does not seek to modify 
and improve society and the environment, but is surrounded and captured by the environment, and thus, compatibility has radically negative and destructive effects (Isaei \& Namdari, 2006).

In fact, organizational culture by introducing desirable behavioral patterns to employees can control their behavior (Mahmoudi, 2005). The importance of organizational culture in shaping the behavior of employees and connecting its internal commitment is to the extent that it can create a kind of commitment and sense of responsibility in people like an informal organization.

In the following the typology of organizational culture studies to specify which model can be used in this research is addressed (Table 1).

Table 1.

Typologies of Organizational Culture

\begin{tabular}{|c|c|c|c|c|c|}
\hline & Models & Cultures & & & \\
\hline & Parsons & Adaptation & $\begin{array}{l}\text { Achieving the } \\
\text { Goal }\end{array}$ & Merge & Commune \\
\hline & Hofstede & Rational & Ideological & Participatory & Hierarchical \\
\hline & $\begin{array}{l}\text { Dale and } \\
\text { Kennedy }\end{array}$ & Work & Conditional & Process & Mako \\
\hline & $\begin{array}{l}\text { Sunan and } \\
\text { Field }\end{array}$ & Scientific & Club & Group & Sangari \\
\hline & Denison & Flexible & Mission & Participatory & Continuity \\
\hline & Charles Hindi & Task & Power & Personal & Network \\
\hline & $\begin{array}{l}\text { Cook and } \\
\text { Lafferty }\end{array}$ & Constructive & Passive & Aggressive & --- \\
\hline & Two S Cubes & Network & Hired & Scattered & Common \\
\hline & $\begin{array}{l}\text { Hellrigel and } \\
\text { Slocum }\end{array}$ & Bureaucratic & Competitive & Participatory & Learner \\
\hline & $\begin{array}{l}\text { Hoffman An- } \\
\text { drew }\end{array}$ & Club & Entrepreneurship & Market & Hierarchical \\
\hline & Trumpnars & Tribal & Bureaucratic & $\begin{array}{l}\text { Objective Orient- } \\
\text { ed }\end{array}$ & Greenhouse \\
\hline & Robbins & Group & Military Service & Piece by Piece & Network \\
\hline & Slobodnik & Open System & Closed System & Coordinated & Accidental \\
\hline & Soltani & Idealistic & $\begin{array}{l}\text { Transcendent- } \\
\text { oriented }\end{array}$ & Transformational & $\begin{array}{l}\text { Focus- } \\
\text { oriented }\end{array}$ \\
\hline
\end{tabular}

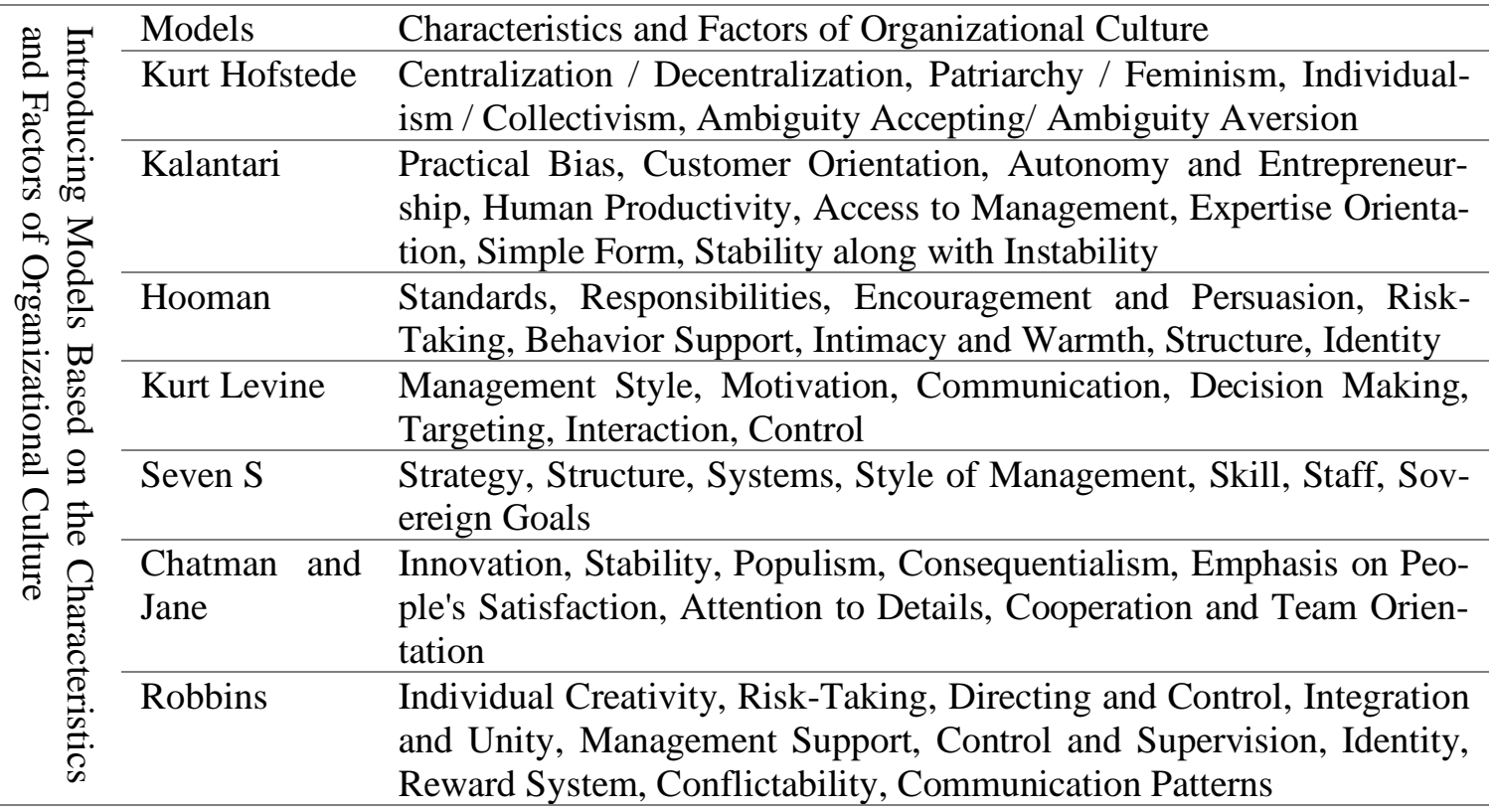


According to the models presented above, in this research, the following dimensions as well as the opinions of experts are used to measure organizational culture, regarding their appropriateness and proximity to the research topic and the organization under study:

- Having a mission (Delkhamoush, 2012)

- Adaptability (Brown, 2006)

- Flexibility (Maruyama Jeffrey, 2010)

- Rationality (Hoffman Andrew, 1993)

- Participation (Hofstede, 2001)

- Structure (Hooman, 2008)

- Warmth and intimacy (Dollinger et al., 1996)

- Conflict (Schwartz, 2006)

- Identity (Roche, 2007)

- Support and protect (Bilsky \& Schwartz, 1994)

- Standards (Soltani, 2012)

- Independence and entrepreneurship (Kalantari, 2008)

- Human resources productivity (Marigi, 2010)

- Practical bias (Abzari \& Dalvi, 2006)

- Customer orientation (Ghasemi, 2013)

\section{Personal Values}

The word value terminologically is a relatively stable belief or faith that a person by relying on it prefers a particular behavior method or an ultimate state, which is personal or social, to a particular behavior or an ultimate state, which is contrary to the selected state. According to numerous definitions, the definition that refers more to the guidance of values is the definition of Bruce Cohen, who writes: "Values are rooted beliefs that the social group, when asking about the good and the bad and the desired perfection refer to" (Marigi, 2010). Values as one of the most fundamental elements in determining and constructing the ways of action, feeling and thought of human beings in the field of social life, have a key role and in fact are the reflection of the material and psychological needs of human beings and the crystallization of the state of interaction and social relationships, which have been defined in various meanings, including rooted emotions and determining the part of behavior and a kind of ideal and desirability of the way of acting or being (Karami \& Hashemzadeh, 2013). According to (Bryce, 2012), "Value" is defined as the enduring belief about a particular mode of behavior or ultimate goal that is individually or socially preferable to another mode of behavior or goal. values are trans-situational, desirable and different goals in importance that act as guiding principles in the lives of individuals.

(Miser Lawrence \& Gamest, 2012) have conducted the first and most important researches in the field of determining and classifying values, they identified and classified six types of values (Schultz Duane, 1990), which include: scientific values (knowledge), political values (power), aesthetic values (art), economic values (wealth), social values (fame) and religious values (Table 2).

Table 2.

Typology of Personnel Values Theories (Researcher)

\begin{tabular}{|c|c|c|}
\hline \multirow{3}{*}{ 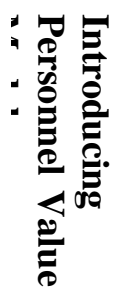 } & Theory & Dimensions \\
\hline & $\begin{array}{l}\text { Miser Lawrence \& Gam- } \\
\text { est }\end{array}$ & $\begin{array}{l}\text { Scientific values (knowledge), political values (power), } \\
\text { aesthetic values (art), economic values (wealth), social } \\
\text { values (fame) and religious values }\end{array}$ \\
\hline & Rakeach & $\begin{array}{l}\text { Ultimate Values (comfortable life, exciting life, having a } \\
\text { sense of accomplishment, a world full of peace and tran- } \\
\text { quility, a world full of beauty, equality, family security, }\end{array}$ \\
\hline
\end{tabular}


freedom, happiness, internal harmony, mature love, national security, pleasure, salvation, self-respect, being recognized in society, true friendship, wisdom), Instrumental Values (ambitious, intellectual, capable, happy, pure, courage, being generous, being helpful, honesty, having imagination, independent, wise, rational, loving, obedience, polite, responsible, self-control)

Schwartz Benevolence (striving to maintain the comfort and welfare of others), traditionalism (adherence to cultural and religious customs), conformity (curbing desirable social actions and impulses), security (health and stabilization of the status of oneself and society), power (controlling individuals and resources), success (gaining competence according to community standards), provocation (excitement, modernity, militancy), universalism (protection and support of man and nature), hedonism (global desire and pleasure) and self-guidance (independent thoughts and actions)

Sherry Verma $\quad$ Religious values, social values, popular values, aesthetic values, economic values, knowledge value, hedonic value, power value, family prestige value, health value

Hultman and Gellermann Human development, justice, freedom, choice, balance of independence and constraint

Hamidi et al Achieving goals, helping and caring for others, honesty, to be fair

Rajaipour \& Lafti Loyalty, honesty, cooperation, order, stability, responsibility

Gorjipour

Freedom, impartiality, independence, commitment, progress, rationality, perseverance, democracy, religiosity, honesty, equality, sacrifice, respect for others, cooperation, altruism, materialism, having authority, self-control, restraint, money and wealth, loyalty, responsibility, purposefulness, saving, adaptation and coordination, creativity, unity and solidarity, competence, satisfaction

According to the models presented above, in this research, the following dimensions are used to measure personnel values, regarding their appropriateness and proximity to the research topic and the organization under study, as well as the opinions of experts:

- Successism (Schwartz, 1992)

- Power (Schwartz, 1992)

- Security (Schwartz, 1992)

- Tradition (Schwartz, 1992)

- Benevolence (Schwartz, 1992)

- Generalism (Schwartz, 1992)

- Self-reliance (Schwartz, 1992)

- Motivation (Schwartz, 1992)

- Welfare seeking (Schwartz, 1992)

- Adaptability (Schwartz, 1992)

- Achievement of objectives (Schwartz, 1992)

- Helping others (Hamidi et al, 2013)

- Honesty (Hamidi et al, 2013)

- To be fair (Hamidi et al, 2013)

- Responsibility (Hamidi et al, 2013)

- Loyalty (Gorjipour, 2015)

- Creativity (Gorjipour, 2015) 
Research Theoretical Framework

Based on the previous theoretical points and the review of the theoretical concepts studied in this article, the following model is drawn as the proposed research model (Figure 1):

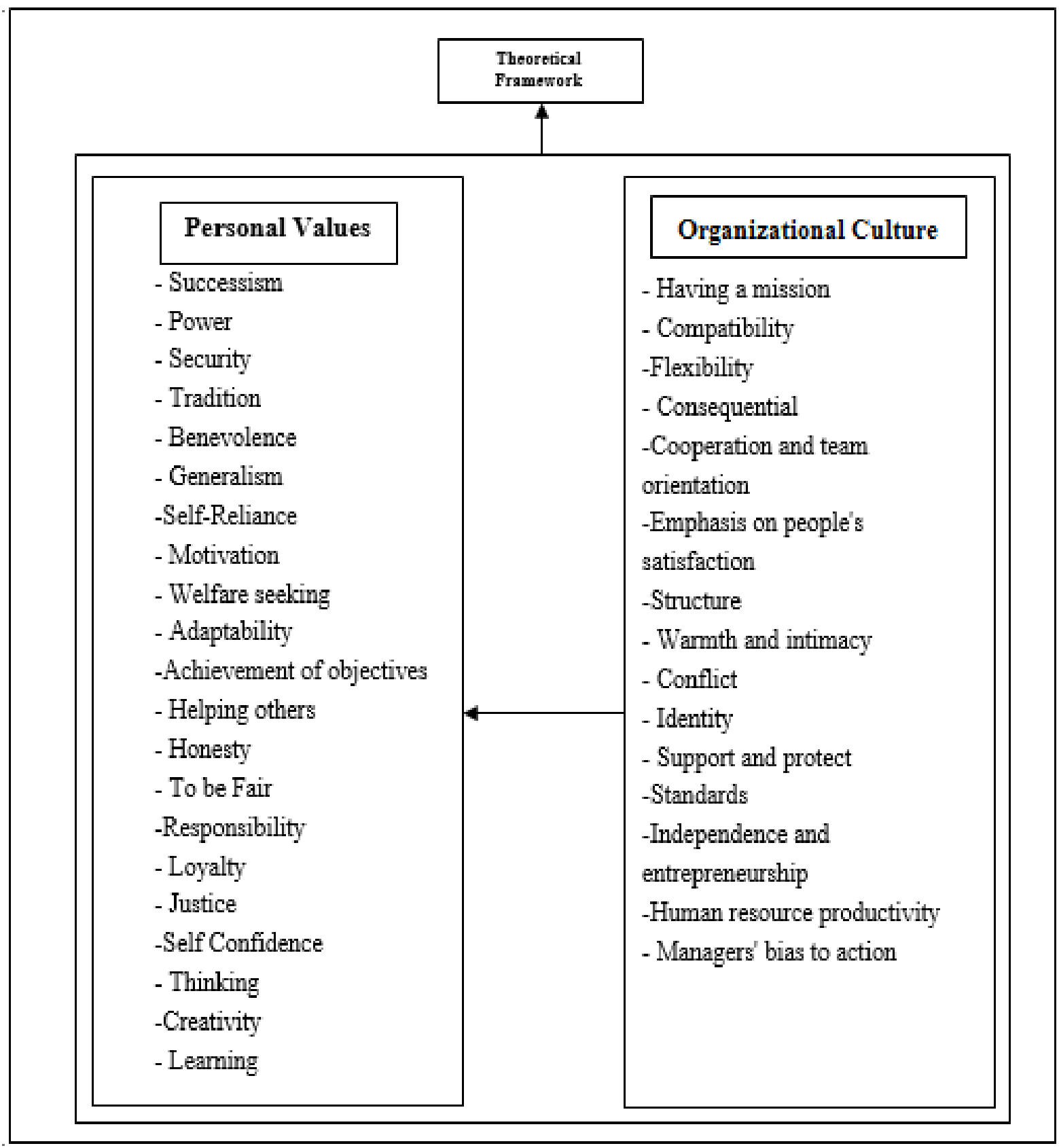

Figure 1. Initial Research Conceptual Model (Researcher)

\section{Materials and Methods}

Statistical Population and Sampling Method

The statistical population of this research is 3,622 Bandar Imam Petrochemical personnel, of which we have selected 595 people as sample. The required information has been collected by stratified random sampling method. 


\section{Data Collection Tool}

In this research, in order to review the literature of the topic under study, the library method has been used and in order to collect field data, a questionnaire has been used. The researcher-made questionnaire of organizational culture includes 73 items and personnel values include 85 items. In order to prepare the questionnaire, the help of theoretical foundations and existing standard questionnaires has been taken. However, the content validity of the entire questionnaire was assessed and confirmed by 5 professors, expert in this field using Delphi method. In order to further increase the validity of the questionnaire, construct validity was also used and at this stage, confirmatory factor analysis was used for each one of the dimensions separately.

\section{Results}

Data Analysis Method

Statistical analysis of data was performed using SPSS 21 and LISREL software. The main and demographic variables of the research were described by frequency, frequency percentage, and mean and standard deviation indicators. The validity and reliability of the research tool were evaluated using confirmatory factor analysis and Cronbach's alpha. Structural equations modeling (SEM) technique was used to test the model and to test the hypotheses. Maximum alpha error level for testing hypotheses is $0.05(\mathrm{P} \leq 0.05)$.

\section{Descriptive Findings}

In (Table 3) the frequency of classes of demographic variables (gender, level of education, years of service and organizational position) has been reported. Findings show that most respondents (72\%) are male. Most of the respondents have a bachelor educational degree $(61 \%)$ and are expert in terms of organizational position (90\%). Findings show that $44 \%$ of people have higher than 20 years of work experience.

Table 3.

Demographic Characteristics of the Sample $(N=250)$

\begin{tabular}{cccccc}
\hline Characteristic & Frequency & $\begin{array}{c}\text { Frequency } \\
\text { Percentage }\end{array}$ & Characteristic & Frequency & $\begin{array}{c}\text { Frequency } \\
\text { Percentage }\end{array}$ \\
\hline Gender & & \multicolumn{5}{c}{ Education } & \\
\hline Female & 163 & 27.4 & Diploma & 68 & 11.4 \\
\hline Male & 432 & 72.6 & Associate & 36 & 6.1 \\
\hline $\begin{array}{c}\text { Service Years } \\
\text { Less than 5 } \\
\text { Years }\end{array}$ & 10 & 1.7 & Bachelor & 368 & 61.8 \\
\hline $\mathbf{5}$ to 10 Years & 37 & 6.2 & $\begin{array}{c}\text { Master } \\
\text { Organizational } \\
\text { Position }\end{array}$ & 123 & 20.7 \\
\hline $\mathbf{1 1}$ to 15 Years & 120 & 20.2 & $\begin{array}{c}\text { Inspector and } \\
\text { Head of Office }\end{array}$ & 39 & 6.6 \\
\hline $\mathbf{1 6}$ to 20 Years & 163 & 27.4 & $\begin{array}{c}\text { Supervisor and } \\
\text { Expert }\end{array}$ & 541 & 90.9 \\
\hline $\begin{array}{l}\text { Higher than } \\
\text { 20 Years }\end{array}$ & 265 & 44.5 & $\begin{array}{c}\text { Senior Manag- } \\
\text { er and Deputy }\end{array}$ & 15 & 2.5 \\
\hline
\end{tabular}

Evaluating the Validity and Reliability of Research Tool

Confirmatory factor analysis technique was used to evaluate the validity of the research tool and internal synchronization and Cronbach's alpha methods were used to evaluate the relia- 
bility. In confirmatory factor analysis, the researcher seeks to evaluate the proposed measurement model. Confirmatory factor analysis is a technique that shows to what extent the allocation of items to hidden variables is consistent with the collected data. Confirmatory factor analysis evaluates measurement based on one-dimensionality, validity, and reliability of concepts (Brown, 2006). Confirmatory factor analysis expresses a deductive approach in which researchers apply a top-down approach by predicting the consequence of a theoretical framework. This consequence is to specify formulation (model) before statistical analysis in which the measured variables are the indicators of the factor. In addition, the formulation or specification of relationships between factors, and the relationships between error expressions should also be predetermined by researchers (Rajaipour \& Lafti, 2010).

Factor loads and reliability values (Cronbach's alpha) have been reported in Tables 4 . Factor loads indicate the ratio of correlation of each item (explicit variable) and every variable (hidden). The factor load value of 0.40 was regarded the basis as the minimum factor load and questions or items with a factor load higher than 0.40 were left in the final analysis. According to the results, all obtained factor loads are higher than 0.40 . Factor loads obtained for all variable questions from are minimally 0.48 to maximally 0.97 .

After investigating the validity of the variables, the reliability of the variables was evaluated. The reliability of the variables was investigated through internal synchronization method and the evaluation of Cronbach's alpha value. If the items (questions) of a scale are to measure the aspects of a structure, then they must have relatively high correlation with each other. One way to measure this is to assess the correlation of each item with other items and examine the matrix. The most common method of calculating reliability is to calculate Cronbach's alpha, which is called the alpha coefficient. This method is related to the mean correlation between each pair of items and the number of items of the related scale. This method is the most common method of calculating reliability and has been reported more than other methods. The general rule is that the Cronbach's alpha value of a scale should be at least 0.70 (Bryce, 2012). Cronbach's alpha values in (Table 4) show that Cronbach's alpha obtained for all variables (or dimensions) is higher than 0.70 that shows all variables have acceptable reliability (Table 5).

\section{Table 4.}

Standard Factor Load and the T Values of Questions Related to Organizational Culture

\begin{tabular}{|c|c|c|c|c|c|}
\hline Structure & \multicolumn{2}{|c|}{$\begin{array}{c}\text { Questionnaire } \\
\text { Question }\end{array}$} & $\begin{array}{l}\text { Standardized } \\
\text { Factor Load }\end{array}$ & $\begin{array}{c}T \\
\text { Value }\end{array}$ & $\begin{array}{c}\text { Cronbach's } \\
\text { Alpha }\end{array}$ \\
\hline \multirow{3}{*}{ Having A Mission } & Question & 1. & 0.651 & - & 0.774 \\
\hline & Question & 2. & 0.794 & 9.498 & \\
\hline & Question & 3. & 0.490 & 9.589 & \\
\hline \multirow[t]{3}{*}{ Compatibility } & Question & 4. & 0.591 & - & 0.726 \\
\hline & Question & 5. & 0.715 & 10.794 & \\
\hline & Question & 6. & 0.675 & 11.672 & \\
\hline \multirow[t]{3}{*}{ Adaptability } & Question & 7. & 0.518 & - & 0.837 \\
\hline & Question & 8. & 0.636 & 8.511 & \\
\hline & Question & 9. & 0.667 & 9.014 & \\
\hline \multirow{4}{*}{$\begin{array}{c}\text { Collaboration } \\
\text { and Team Orien- } \\
\text { tation }\end{array}$} & Question & 10. & 0.585 & - & 0.797 \\
\hline & Question & 11. & 0.506 & 8.940 & \\
\hline & Question & 12. & 0.530 & 8.292 & \\
\hline & Question & 13. & 0.581 & 8.516 & \\
\hline \multirow[t]{4}{*}{ Rationality } & Question & 14. & 0.544 & - & 0.820 \\
\hline & Question & 15. & 0.574 & 9.838 & \\
\hline & Question & 16. & 0.713 & 10.201 & \\
\hline & Question & 17. & 0.617 & 11.323 & \\
\hline
\end{tabular}




\begin{tabular}{|c|c|c|c|c|c|}
\hline \multirow[t]{8}{*}{ Structure } & Question & 18. & 0.542 & - & \multirow[t]{8}{*}{0.895} \\
\hline & Question & 19. & 0.558 & 9.319 & \\
\hline & Question & 20. & 0.605 & 9.481 & \\
\hline & Question & 21. & 0.419 & 9.917 & \\
\hline & Question & 22. & 0.575 & 8.869 & \\
\hline & Question & 23. & 0.585 & 9.647 & \\
\hline & Question & 24. & 0.575 & 9.737 & \\
\hline & Question & 25. & 0.494 & 9.644 & \\
\hline \multirow{5}{*}{$\begin{array}{c}\text { Warmth and In- } \\
\text { timacy }\end{array}$} & Question & 26. & 0.534 & - & \multirow[t]{5}{*}{0.734} \\
\hline & Question & 27. & 0.624 & 2.672 & \\
\hline & Question & 28. & 0.618 & 2.688 & \\
\hline & Question & 29. & 0.278 & 2.688 & \\
\hline & Question & 30. & 0.138 & 2.472 & \\
\hline \multirow[t]{6}{*}{ Standards } & Question & 31. & 0.430 & - & \multirow[t]{6}{*}{0.800} \\
\hline & Question & 32. & 0.254 & 7.631 & \\
\hline & Question & 33. & 0.199 & 5.023 & \\
\hline & Question & 34. & 0.536 & 4.042 & \\
\hline & Question & 35. & 0.702 & 8.785 & \\
\hline & Question & 36. & 0.505 & 9.952 & \\
\hline \multirow[t]{4}{*}{ Conflict } & Question & 37. & 0.724 & - & \multirow[t]{4}{*}{0.792} \\
\hline & Question & 38. & 0.213 & 7.733 & \\
\hline & Question & 39. & 0.518 & 3.978 & \\
\hline & Question & 40. & 0.422 & 7.206 & \\
\hline \multirow[t]{4}{*}{ Identity } & Question & 41. & 0.433 & - & \multirow[t]{4}{*}{0.815} \\
\hline & Question & 42. & 0.559 & 6.486 & \\
\hline & Question & 43. & 0.673 & 7.296 & \\
\hline & Question & 44. & 0.423 & 7.607 & \\
\hline \multirow{5}{*}{$\begin{array}{c}\text { Support and Pro- } \\
\text { tect }\end{array}$} & Question & 45. & 0.409 & - & \multirow[t]{5}{*}{0.877} \\
\hline & Question & 46. & 0.414 & 5.951 & \\
\hline & Question & 47. & 0.172 & 5.990 & \\
\hline & Question & 48. & 0.555 & 3.089 & \\
\hline & Question & 49. & 0.461 & 6.751 & \\
\hline \multirow{8}{*}{$\begin{array}{l}\text { Independence } \\
\text { and Entrepre- } \\
\text { neurship }\end{array}$} & Question & 50. & 0.295 & 6.033 & \multirow[t]{8}{*}{0.815} \\
\hline & Question & 51. & 0.342 & - & \\
\hline & Question & 52. & 0.447 & 7.068 & \\
\hline & Question & 53. & 0.571 & 8.852 & \\
\hline & Question & 54. & 0.625 & 10.630 & \\
\hline & Question & 55. & 0.636 & 11.306 & \\
\hline & Question & 56. & 0.717 & 11.441 & \\
\hline & Question & 57. & 0.571 & 12.284 & \\
\hline \multirow{6}{*}{$\begin{array}{c}\text { Human Resource } \\
\text { Productivity }\end{array}$} & Question & 58. & 0.642 & 10.265 & \multirow[t]{6}{*}{0.764} \\
\hline & Question & 59. & 0.582 & - & \\
\hline & Question & 60. & 0.722 & 6.158 & \\
\hline & Question & 61. & 0.765 & 6.411 & \\
\hline & Question & 62. & 0.536 & 6.457 & \\
\hline & Question & 63. & 0.535 & 5.035 & \\
\hline \multirow{4}{*}{$\begin{array}{l}\text { Managers' Bias } \\
\text { in Action }\end{array}$} & Question & 64. & 0.378 & 7.844 & \multirow[t]{4}{*}{0.739} \\
\hline & Question & 65. & 0.465 & - & \\
\hline & Question & 66. & 0.548 & 8.454 & \\
\hline & Question & 67. & 0.641 & 9.491 & \\
\hline \multirow{3}{*}{$\begin{array}{c}\text { Customer Orien- } \\
\text { tation }\end{array}$} & Question & 68. & 0.492 & - & \multirow[t]{3}{*}{0.854} \\
\hline & Question & 69. & 0.461 & 9.543 & \\
\hline & Question & 70. & 0.471 & 6.801 & \\
\hline
\end{tabular}




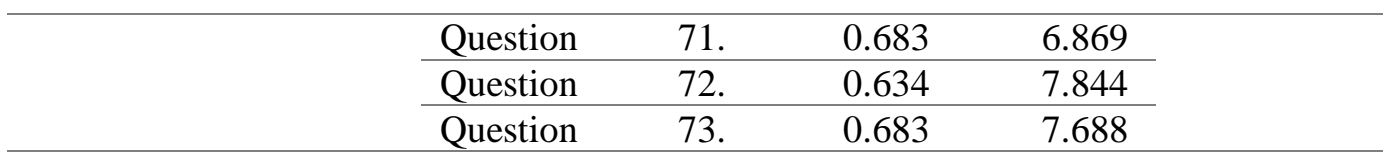

Table 5.

Standard Factor Load and the T Values of Questions Related to Personnel Values

\begin{tabular}{|c|c|c|c|c|c|}
\hline Structure & & naire & $\begin{array}{c}\text { Standardized } \\
\text { Factor Load }\end{array}$ & $\begin{array}{c}\text { T Val- } \\
\text { ue }\end{array}$ & $\begin{array}{c}\text { Cronbach's } \\
\text { Alpha }\end{array}$ \\
\hline \multirow[t]{4}{*}{ Successism } & Question & 1. & 0.186 & 3.473 & 0.748 \\
\hline & Question & 2. & 0.285 & 5.047 & \\
\hline & Question & 3. & 0.666 & 6.926 & \\
\hline & Question & 4. & 0.625 & - & \\
\hline \multirow{4}{*}{$\begin{array}{c}\text { Achievement of } \\
\text { objectives }\end{array}$} & Question & 5. & 0.632 & 8.520 & 0.716 \\
\hline & Question & 6. & 0.722 & 8.822 & \\
\hline & Question & 7. & 0.596 & 8.334 & \\
\hline & Question & 8. & 0.442 & - & \\
\hline \multirow[t]{5}{*}{ Security } & Question & 9. & 0.529 & 10.499 & 0.728 \\
\hline & Question & 10. & 0.688 & 12.764 & \\
\hline & Question & 11. & 0.795 & 13.811 & \\
\hline & Question & 12. & 0.673 & 12.568 & \\
\hline & Question & 13. & 0.610 & - & \\
\hline \multirow{4}{*}{$\begin{array}{l}\text { Help and care } \\
\text { for others }\end{array}$} & Question & 14. & 0.667 & 9.524 & 0.841 \\
\hline & Question & 15. & 0.566 & 8.949 & \\
\hline & Question & 16. & 0.393 & 7.029 & \\
\hline & Question & 17. & 0.550 & - & \\
\hline \multirow[t]{4}{*}{ Benevolence } & Question & 18. & 0.661 & 11.058 & 0.752 \\
\hline & Question & 19. & 0.572 & 10.131 & \\
\hline & Question & 20. & 0.737 & 11.562 & \\
\hline & Question & 21. & 0.574 & - & \\
\hline \multirow[t]{3}{*}{ Responsibility } & Question & 22. & 0.591 & 11.575 & 0.796 \\
\hline & Question & 23. & 0.739 & 13.067 & \\
\hline & Question & 24. & 0.706 & & \\
\hline \multirow[t]{4}{*}{ Self-Reliance } & Question & 25. & 0.648 & 12.251 & 0.702 \\
\hline & Question & 26. & 0.715 & 13.069 & \\
\hline & Question & 27. & 0.724 & 13.173 & \\
\hline & Question & 28. & 0.623 & - & \\
\hline \multirow[t]{4}{*}{ Loyalty } & Question & 29. & 0.644 & 11.784 & 0.763 \\
\hline & Question & 30. & 0.702 & 12.401 & \\
\hline & Question & 31. & 0.616 & 11.432 & \\
\hline & Question & 32. & 0.624 & - & \\
\hline \multirow[t]{3}{*}{ Pleasure } & Question & 33. & 0.668 & 11.369 & 0.777 \\
\hline & Question & 34. & 0.664 & 11.344 & \\
\hline & Question & 35. & 0.674 & - & \\
\hline \multirow[t]{4}{*}{ Justice } & Question & 36. & 0.534 & 9.250 & 0.761 \\
\hline & Question & 37. & 0.725 & 10.602 & \\
\hline & Question & 38. & 0.580 & 9.749 & \\
\hline & Question & 39. & 0.574 & - & \\
\hline \multirow[t]{4}{*}{ Self Confidence } & Question & 40. & 0.624 & 8.578 & 0.788 \\
\hline & Question & 41. & 0.733 & 9.008 & \\
\hline & Question & 42. & 0.637 & 8.644 & \\
\hline & Question & 43. & 0.434 & - & \\
\hline
\end{tabular}




\begin{tabular}{|c|c|c|c|c|c|}
\hline \multirow[t]{3}{*}{ Power } & Question & 44. & 0.571 & 8.672 & \multirow[t]{3}{*}{0.748} \\
\hline & Question & 45. & 0.681 & 8.868 & \\
\hline & Question & 46. & 0.567 & - & \\
\hline \multirow[t]{4}{*}{ Honesty } & Question & 47. & 0.575 & 7.850 & \multirow[t]{4}{*}{0.769} \\
\hline & Question & 48. & 0.668 & 8.239 & \\
\hline & Question & 49. & 0.685 & 8.277 & \\
\hline & Question & 50. & 0.430 & - & \\
\hline \multirow[t]{4}{*}{ Conformity } & Question & 51. & 0.617 & 12.693 & \multirow[t]{4}{*}{0.714} \\
\hline & Question & 52. & 0.676 & 13.678 & \\
\hline & Question & 53. & 0.830 & 15.365 & \\
\hline & Question & 54. & 0.669 & - & \\
\hline \multirow[t]{4}{*}{ To be fair } & Question & 55. & 0.480 & 9.913 & \multirow[t]{4}{*}{0.759} \\
\hline & Question & 56. & 0.688 & 13.307 & \\
\hline & Question & 57. & 0.797 & 14.283 & \\
\hline & Question & 58. & 0.659 & - & \\
\hline \multirow[t]{3}{*}{ Provocation } & Question & 59. & 0.696 & 11.875 & \multirow[t]{3}{*}{0.777} \\
\hline & Question & 60. & 0.647 & 11.637 & \\
\hline & Question & 61. & 0.715 & - & \\
\hline \multirow[t]{5}{*}{ Thinking } & Question & 62. & 0.359 & 9.797 & \multirow[t]{5}{*}{0.798} \\
\hline & Question & 63. & 0.485 & 8.531 & \\
\hline & Question & 64. & 0.705 & 10.375 & \\
\hline & Question & 65. & 0.647 & 10.098 & \\
\hline & Question & 66. & 0.553 & - & \\
\hline \multirow[t]{4}{*}{ Tradition } & Question & 67. & 0.461 & 8.218 & \multirow[t]{4}{*}{0.718} \\
\hline & Question & 68. & 0.634 & 9.979 & \\
\hline & Question & 69. & 0.734 & 10.205 & \\
\hline & Question & 70. & 0.565 & - & \\
\hline \multirow[t]{4}{*}{ Creativity } & Question & 71. & 0.614 & 9.511 & \multirow[t]{4}{*}{0.744} \\
\hline & Question & 72. & 0.709 & 10.008 & \\
\hline & Question & 73. & 0.527 & 8.748 & \\
\hline & Question & 74. & 0.522 & - & \\
\hline \multirow[t]{6}{*}{ Universalism } & Question & 75. & 0.522 & 6.570 & \multirow[t]{6}{*}{0.868} \\
\hline & Question & 76. & 0.678 & 7.058 & \\
\hline & Question & 77. & 0.599 & 6.853 & \\
\hline & Question & 78. & 0.628 & 6.940 & \\
\hline & Question & 79. & 0.492 & 6.431 & \\
\hline & Question & 80. & 0.343 & - & \\
\hline \multirow{5}{*}{ Learning } & Question & 81. & 0.514 & 9.789 & \multirow[t]{5}{*}{0.700} \\
\hline & Question & 82. & 0.637 & 11.360 & \\
\hline & Question & 83. & 0.808 & 12.749 & \\
\hline & Question & 84. & 0.709 & 12.095 & \\
\hline & Question & 85. & 0.568 & - & \\
\hline
\end{tabular}

\section{Investigating Fit Indices}

After estimating the model parameters, the question that arises is that to what extent the desired model is compatible with the relevant data. The answer to this question is possible only by examining the fitness of the model. Therefore, in the analysis of structural equations, the researcher must ensure the fitness of the model after estimating the parameters and before interpreting them (Kalantari, 2008). In the following some of the most important fit indicators have been reported.

(Mahmoudi, 2005) suggests the following criteria for evaluating the RMSEA index: a) less than 0.08 . means a good fit, b) 0.08 to 0.10 means medium fit, c) more than 0.10 means 
weak. The goodness of fit index (GFI), the comparative fit index (CFI) and the normed fit index (NFI) are generally in the range between zero and one. Coefficients that are higher than 0.90 are considered acceptable; although this, like the level of $\mathrm{P}=0.05$ is optional (Hooman, 2008: 43). Also, if the value of the Chi-square ratio index to the degree of freedom is lower than 3 , it indicates an acceptable fit of the model. If the significance level is also obtained more than 0.05 , it indicates a proper fit of the model with the data. For the parsimony goodness of fit index (PGFI), the values higher than 0.60 have also been considered acceptable (Ghasemi, 2013). Another important point that should be considered is that the fit of the model should be evaluated through various methods and criteria to examine its fitness from various dimensions (Table 6).

Table 6.

Fit Indicators of the Research Proposed Model

\begin{tabular}{ccc}
\hline \multicolumn{1}{c}{ Index } & Acceptable Limit & $\begin{array}{c}\text { Reported } \\
\text { Value }\end{array}$ \\
\hline $\begin{array}{c}\text { Root Mean Square Error of Ap- } \\
\text { proximation (RMSEA) }\end{array}$ & Equal to or lower than 0.08 & 0.051 \\
\hline $\begin{array}{c}\text { Normalized Chi-Square } \\
\text { (CMIN/DF) }\end{array}$ & Equal to or lower than 3 & 1.651 \\
\hline $\begin{array}{c}\text { Goodness of Fit Index (GFI) } \\
\text { Adjusted Goodness of Fit Index } \\
\text { (AGFI) }\end{array}$ & Equal to or higher than 0.9 & 0.933 \\
\hline $\begin{array}{c}\text { Comparative Fit Index (CFI) } \\
\text { Normed Fit Index (NFI) }\end{array}$ & Equal to or higher than 0.9 & 0.899 \\
\hline Tucker-Lewis Index (TLI) & Equal to or higher than 0.9 & 0.968 \\
\hline Incremental Fit Index (NFI) & Equal to or higher than 0.9 & 0.957 \\
\hline
\end{tabular}

\section{Research Model Test}

Structural equation methods estimate the ratio and intensity of hypothetical relationships between variables in a theoretical model. These techniques show the direct effect of one variable on another variable as well as the effect of another variable located between these two variables (intervening or mediating variables). If it can be assumed that the hypothetical model is correct, it can be said that the information resulting from the model shows exactly the basic (causal) processes between variables (Maruyama Jeffrey, 2010). Structural equation modeling tests causal models with a linear equation system based on hypotheses about the existence of causal relationships between variables. Thus, modeling tests the theoretical relationships between definite and assumed structural conditions and makes causal estimation between latent (unobserved or hidden) variables as well as relationships between measured variables (observed or apparent) possible. In general, it can be said that by examining variances and co-variances, we can test this hypothesis that "variables are related with each other through a set of linear relationships". The structural model of the research has been presented in the following. (Figure 2) shows the research model in the standard coefficients state. In the following, we will examine the fit indices and model coefficients. 


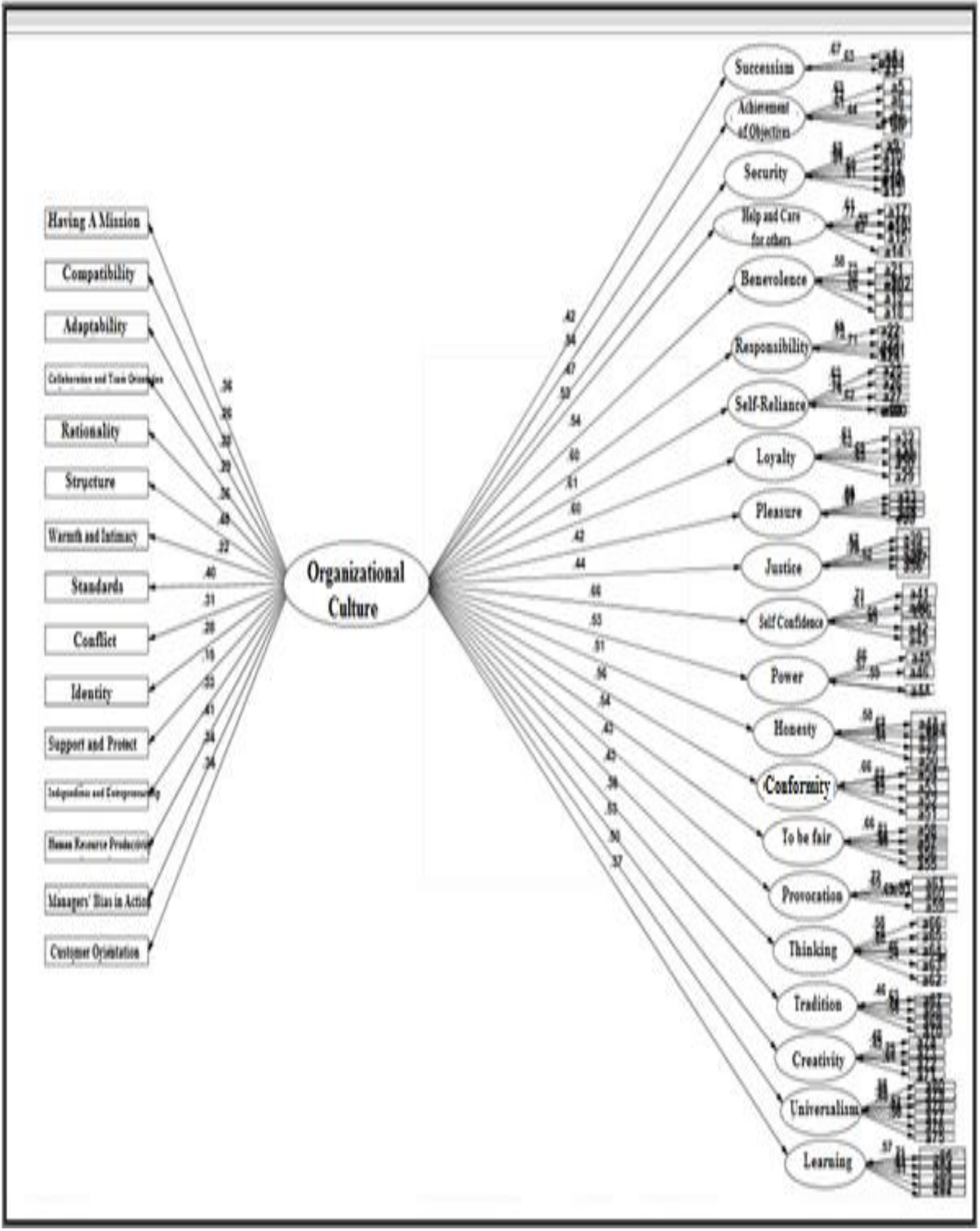

Figure 2. Results of Structural Equations to Investigate the Proposed Research Model

(Standardized Factor Load)

\section{Testing Research Hypotheses}

In (Table 7) the results related to testing research hypotheses have been reported. The basis for testing research hypotheses is a structural model. The standardized path coefficient value and the $\mathrm{t}$ test value have been reported. In relation to t-test, as the research tests are directional, the significance level of a range is considered. As a result, if the $t$ value is higher than 1.65 , it means that the relationship obtained at the error level of less than 0.05 . is significant $(\mathrm{P}<0.05)$, and if the $t$ value is higher than 1.96, it means that the relationship obtained at the error level of less than 0.01, has become significant $(\mathrm{P}<0.01)$. As it is observed, investigating the relationship 
and the research conceptual model show that all research hypotheses have been confirmed at the $99 \%$ confidence level $(\mathrm{P} \leq 0.01)$.

Table 7.

Path Coefficient and Its Significance and Investigating the Research Question in the Main Path Analysis Model

\begin{tabular}{|c|c|c|c|c|}
\hline Question & $\begin{array}{l}\text { Path Coef- } \\
\text { ficient }\end{array}$ & $\mathrm{T}$ Value & Result & $\begin{array}{l}\text { Type of Rela- } \\
\text { tionship }\end{array}$ \\
\hline Successism $\rightarrow$ Personal Values & 0.419 & $5.163 * *$ & $\begin{array}{l}\text { Question Con- } \\
\text { firmed }\end{array}$ & Incremental \\
\hline $\begin{array}{l}\text { Achievement of objectives } \\
\rightarrow \text { Personal Values }\end{array}$ & 0.543 & $5.660 * *$ & $\begin{array}{l}\text { Question Con- } \\
\text { firmed }\end{array}$ & Incremental \\
\hline Security $\rightarrow$ Personal Values & 0.466 & $6.096^{* *}$ & $\begin{array}{l}\text { Question Con- } \\
\text { firmed }\end{array}$ & Incremental \\
\hline $\begin{array}{l}\text { Helping and Caring for Others } \\
\rightarrow \text { Personal Values }\end{array}$ & 0.524 & $6.292 * *$ & $\begin{array}{l}\text { Question Con- } \\
\text { firmed }\end{array}$ & Incremental \\
\hline $\begin{array}{c}\text { Benevolence } \\
\text { ues }\end{array}$ & 0.538 & $6.224 * *$ & $\begin{array}{l}\text { Question Con- } \\
\text { firmed }\end{array}$ & Incremental \\
\hline $\begin{array}{c}\text { Responsibility } \rightarrow \text { Personal } \\
\text { Values }\end{array}$ & 0.603 & $6.750 * *$ & $\begin{array}{l}\text { Question Con- } \\
\text { firmed }\end{array}$ & Incremental \\
\hline $\begin{array}{c}\text { Self-Reliance flersonal Val- } \\
\text { ues }\end{array}$ & 0.609 & $6.670^{* *}$ & $\begin{array}{l}\text { Question Con- } \\
\text { firmed }\end{array}$ & Incremental \\
\hline Loyalty $\rightarrow$ Personal Values & 0.602 & $6.568 * *$ & $\begin{array}{l}\text { Question Con- } \\
\text { firmed }\end{array}$ & Incremental \\
\hline Hedonism $\rightarrow$ Personal Values & 0.442 & $5.666 * *$ & $\begin{array}{l}\text { Question Con- } \\
\text { firmed }\end{array}$ & Incremental \\
\hline Justice $\rightarrow$ Personal Values & 0.418 & $5.679 * *$ & $\begin{array}{l}\text { Question Con- } \\
\text { firmed }\end{array}$ & Incremental \\
\hline $\begin{array}{c}\text { Self-Confidence } \rightarrow \text { Personal } \\
\text { Values }\end{array}$ & 0.657 & $6.052 * *$ & $\begin{array}{l}\text { Question Con- } \\
\text { firmed }\end{array}$ & Incremental \\
\hline Power $\rightarrow$ Personal Values & 0.530 & $5.919 * *$ & $\begin{array}{l}\text { Question Con- } \\
\text { firmed }\end{array}$ & Incremental \\
\hline Honesty $\rightarrow$ Personal Values & 0.151 & $9.539 * *$ & $\begin{array}{l}\text { Question Con- } \\
\text { firmed }\end{array}$ & Incremental \\
\hline Conformity $\rightarrow$ Personal Values & 0.560 & $6.635 * *$ & $\begin{array}{l}\text { Question Con- } \\
\text { firmed }\end{array}$ & Incremental \\
\hline To Be Fair $\rightarrow$ Personal Values & 0.538 & $6.490 * *$ & $\begin{array}{l}\text { Question Con- } \\
\text { firmed }\end{array}$ & Incremental \\
\hline 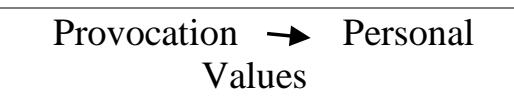 & 0.425 & $5.843 * *$ & $\begin{array}{l}\text { Question Con- } \\
\text { firmed }\end{array}$ & Incremental \\
\hline Thinking $\rightarrow$ Personal Values & 0.429 & $5.630 * *$ & $\begin{array}{l}\text { Question Con- } \\
\text { firmed }\end{array}$ & Incremental \\
\hline Tradition $\rightarrow$ Personal Values & 0.361 & $5.119 * *$ & $\begin{array}{l}\text { Question Con- } \\
\text { firmed }\end{array}$ & Incremental \\
\hline Creativity $\begin{array}{l}\rightarrow \text { Personal Val- } \\
\text { ues }\end{array}$ & 0.532 & $5.803 * *$ & $\begin{array}{l}\text { Question Con- } \\
\text { firmed }\end{array}$ & Incremental \\
\hline $\begin{array}{c}\text { Universalism } \\
\text { Values }\end{array}$ Personal & 0.497 & $5.254 * *$ & $\begin{array}{l}\text { Question Con- } \\
\text { firmed }\end{array}$ & Incremental \\
\hline $\begin{array}{c}\text { Learning } \underset{\text { ues }}{\rightarrow \text { Personal Val- }} \\
\text { - }\end{array}$ & 0.370 & $5.409 * *$ & $\begin{array}{l}\text { Question Con- } \\
\text { firmed }\end{array}$ & Incremental \\
\hline
\end{tabular}




\section{Conclusion}

This research was conducted with the aim of providing a theoretical framework based on the components of organizational culture and personnel values (Case study: Bandar Imam Petrochemical). Thus, after studying the research history and literature and investigating researches related to the topic, as well as investigating and consulting professors and experts to test the hypotheses, a researcher-made questionnaire was used, which includes multiple-choice questions of the Likert's spectrum. To assess the reliability, the questionnaire was distributed among a sample of 30 people of the statistical population, and Cronbach's alpha obtained for all variables was higher than the standard value (0.7), which confirmed the reliability of the questionnaire. The validity of the questionnaire was also confirmed by the supervisor and advisor professors and relevant experts. The statistical population of the research included Bandar Imam Petrochemical personnel and the questionnaire was distributed among 595 personnel as sample size. After collecting the desired data, descriptive and inferential statistical techniques and indicators were used to analyze them.

Investigating the findings in the sample under study shows that organizational culture and personnel values have a positive and significant relationship with each other. Also, the research results show the dimensions of organizational culture (having a mission, adaptability, flexibility, rationality, participation, structure, warmth and intimacy, conflict, identity, support and protect, standards, independence and entrepreneurship, human resource productivity, practical bias, and customer orientation) have a positive and significant relationship with personnel values. These findings are consistent with the research findings of (Bilsky \& Schwartz, 1994) and (Soltani, 2012) and (Kalantari, 2008) and (Abzari \& Dalvi, 2006) and (Ghasemi, 2013).

The present research also had some limitations for researchers that among the limitations, measurement tools can be mentioned. No tested and standard questionnaire was available to measure research variables. The tool of this research is a researcher-made questionnaire that has been used after the validity test. Also, this research has been measured only in Bandar Imam Petrochemical. To increase the generalizability of the research results, it is suggested that such a research be conducted in other public and private organizations. Only the results of such researches and the comparison of organizations in terms of the dimensions of organizational culture and personnel values can lead us to a more comprehensive recognition. Therefore, future researchers are suggested to try to answer the following two questions in line with the present research in other organizations: 1) investigating the research topic in similar organizations and if possible introduce more indicators for measurement, 2) identifying and prioritizing factors affecting the organizational culture and personnel values of Bandar Imam Petrochemical.

\section{References}

Mohseni M. (2013), "General Sociology", Tehran: Tahoori Library, 15(2): 59-64.

Rajaipour S. \& Lafti S. (2010), "Investigating the Relationship between Organizational Culture and the Components of Management Based on Organizational Values, and Presenting a Model for Predicting Management Based on Values (Case Study: Abadeh Education Organization)", Scientific Research Quarterly Journal of New Approach in Educational Management, Islamic Azad University, Marvdasht Branch, 4(1): 125-148.

Robbins S. (2007), "Organization Theory: Structure, Design and Applications", Translated by Ghasem Kabiri, Vol. 3, Tehran: Islamic Azad University, Scientific Center Publication, 15(6): 285-297.

Hatch M. (2009), "Theory of Modern, Symbolic, Interpretive and Postmodern Organization", Translated by Hassan Danaeifard, Tehran: Publication of Afkar, 20(5): 48-56. 
Šahić E. \& Stupar S. (2014), Employee Perceptions of Organizational Culture and Individual Values Based on Examples of Companies in Bosnia and Herzegovina, International Journal of Business and Social Science, 7(1): 179-190.

Mosadeghrad A. (2006), The impact of organizational culture on the successful implementation of total quality management. TQM Journal;18(6): 606-625.

Tolmats E. (2003), Relationship between organisational culture and individual values of the Russian-speaking members of an organisation in Lithuania, Chapter 6 in Organisational Culture in Estonia: Manifestations and Consequences, 16(2): 118-134.

Ahmadi M. (2005), "A Look at Work Conscience and Organizational Culture with a Religious Approach", Tehran: Publication of Zamzam Hedayat, 15(3): 114-128

Mahmoudi M. (2005), "The Role of Organizational Culture in Preventing the Emergence of Corruption", Journal of Tadbir, 16(2): 35-46.

Isaei M. \& Namdari N. (2006), "Organizational Culture of an Efficient Duct", Journal of Selected Management, 56(7): 35-43

Robbins J. (2010), "Organizational Behavior", Translated by Mehdi Zare, Tehran: Nas, 4(3): 59-70.

Delkhamoush M. (2012), "Schwartz Value Survey: Execution Method and Scoring Key, Developmental Psychology-Iranian Psychologists", 24(9): 213-226.

Robbins S. \& Judge T. \& Millett B. \& Boyle M. (2013), Organizational behavior: Pearson Higher Education AU, 19(5): 130-148.

Brown T. (2006), Confirmatory Factor Analysis for Applied Research. New York: The Guildford Press, 18(3): 110-129.

Maruyama Jeffrey M. (2010), "Principles of Structural Equation Modeling", Translated by Samad Rasoulzadeh Aghdam, Tehran: Research Institute for Cultural and Social Studies in collaboration with the Iranian Students Polling Agency (ISPA), 21(9): 28-39.

Hoffman Andrew J. (1993), The importance of fit between individual values and organisational culture in the greening of industry, Business Strategj and the Environment, 8(5): 10-18.

Hofstede G. (2001), Culture's consequences: Comparing values, behaviors, institutions, and organizations across nations, Sage Publications, 11(3): 10-18.

Hooman H. (2008), "Statistical Inference in Behavioral Research" Tehran: Samt, 17(9): 369380.

Dollinger S. \& Leong F. \& Ulicni S. (1996), On traits and values: With special reference to openness to experience. Journal of Research in Personality 30)4): 23-41.

Schwartz S. (2006), Basic human values: Theory, measurement, and applications in. Revue Française de Sociologie, 47(4): 13-30.

Roche G. (2007), Introduction in public sociology, Tehran: Samt Press; 23(1): 250-263.

Bilsky W. \& Schwartz S. (1994), Values and personality; Journal of Personality, 8(2): 163-181.

Soltani M. (2012), "Analysis of the Situation, and Designing the Desired Model of Organizational Culture of One of the Armed Forces Organizations Based on Religious Bases and the Values of the Islamic Revolution", Scientific Research Bi-Quarterly Journal of Islamic Management, 20(1): 99-122.

Kalantari K. (2008), "Structural Equation Modeling in Socio-Economic Researches", Tehran: Farhang-e Saba, 9(2): 410-419.

Marigi S. (2010), Effective factors in deviation of the values, Tehran: Islamic Research Center of IRIB, 16(1): 117-130.

Abzari M. \& Dalvi M. (2006), "Organizational Culture Management (Concepts, Patterns, Change) with Transcendent Orientation Approach", Isfahan: Publication of Ghased-e Sahar, 7(5): 78-96.

Ghasemi V. (2013), "Structural Equation Modeling in Social Researches Using Amos Graphics", Tehran: Sociologists, 29(7): 184-199.

Karami B. \& Hashemzadeh A. (2013), "Sociological Study of Some Value Priorities of the Students of Tarbiat Modares University in Iran and Mysore University in India", Sociological Studies, 2(6): 155-169.

Bryce N. (2012), "Analysis of Psychological Data with SPSS Program", Translated by Khadijeh Aliabadi and Seyed Ali Samadi, Tehran: Publication of Doran, 6(4): 74-80. 
Miser Lawrence S. \& Gamest G. (2012), "Applied Multivariate Research (Design and Interpretation)", Translated by Hassan Pasha Sharifi et al., Tehran: Roshd, 20(5): 116-127.

Schultz Duane P. (1990), Theories of personality. 4th ed. Tehran: Arasbaran Pub, 8(6): 276-80.

Schwartz S. (1992), Universals in the content and structure of values: Theoretical advances and empirical tests in 20 countries, Advances in Experimental Social Psychology, 25(3): 165.

Hamidi O. \& Seifi G. \& Sharifi G. (2013), "The Relationship between Personnel Values and Death Anxiety in Men and Women with MS.", Journal of Psychology, 17(4): 365-380.

Gorjipour K. (2015), "Personnel Values and Organizational Culture", Third International Conference on Applied Researches in Management and Accounting, Tehran: Shahid Beheshti University, 15(2): 119-128 